JURNAL चEEKNOSAINS

\begin{tabular}{lll}
\hline VOLUME 5 & No. 1, 22 Desember 2015 Halaman 1-80
\end{tabular}

\title{
POTENSI TANAMAN DI TAMAN NASIONAL PULAU JAWA SEBAGAI SUMBER BAKTERI PENGHASIL ANTIBIOTIK
}

\author{
Sri Yuwantiningsih \\ Akademi pertanian Yogyakarta \\ Email: sri.yuwantiningsih@yahoo.com \\ Sebastian Margino \\ Jurusan Mikrobiologi Fakultas Pertanian \\ Universitas Gadjah Mada \\ Subagus Wahyuono \\ Jurusan Biologi Farmasi Fakultas Farmasi \\ Universitas Gadjah Mada
}

\begin{abstract}
Bacterial endophytes in trees are potential source to obtain new antibiotic producers that have not been widely studied until now. This study aims to obtain bacterial endophytes isolates in the tissue of twig trees in National Park Banten, Indonesia Germplasm Garden (The Bogor Botanical Gardens), Cilacap Nusakambangan Island, Kaliurang National Park, Meru Betiri National Park Jember, and Baluran National Park, Situbondo. This selection was based on the growth ability in liquid nutrient, GY (glucose and yeast-extract), and antibiotic-3, and the ability to obstruct indicator microbes, such as Bacillus subtilis, Candida albicans, and Fusarium oxysporum. The selection result is obtained eight isolates that have inhibitory effect more than 4, such as BIN-1, KLP-1, OOH-1, STG-1, CMB-2, STL-1, MTG-1, and PPH-1. Based on chromatography method on various eluents, it is obtained three superior isolates, i.e OOH-1,STG-1, and CMB-2. Thus, this shows that bacterial endophytes in trees constitute potential sources for screening new antibiotic producers.
\end{abstract}

Keywords: Antibiotic; Bacterial endophytes; National Park of Java Island

\begin{abstract}
ABSTRAK
Mikrobia endofit dalam pohon merupakan sumber potensial untuk memperoleh penghasil antibiotik baru yang belum banyak diteliti. Penelitian ini dilakuan untuk mendapatkan isolat bakteri endofit dari jaringan ranting pohon di Taman Nasional Ujung Kulon Banten, Kebun Plasma Nutfah Indonesia (Kebun Raya Bogor), Pulau Nusakambangan Cilacap, Taman Nasional Kaliurang, Taman Nasional Meru Betiri Jember dan Taman Nasional Baluran Situbondo. Seleksi dilakukan berdasar atas kemampuan tumbuh dalam medium Nutrien cair, GY (glucose and yeast-extract) dan Antibiotik 3 serta kemampuan menghambat mikrobia indikator Bacillus subtilis, Candida albicans, dan Fusarium oxysporum. Hasil seleksi diperoleh delapan isolat yang memiliki nilai penghambatan hambat lebih dari 4, yaitu BIN-1, KLP-1, OOH-1 ,STG-1, CMB-2, STL-1, MTG-1 dan PPH-1. Berdasarkan penggunaan metode kromatografi kertas pada berbagai eluen didapatkan 3 isolat yang unggul yaitu OOH-1, STG-1, dan CMB-2. Hal ini menunjukkan bahwa mikrobia endofitik dalam pohon merupakan sumber yang potensial untuk mendapatkan penghasil antibiotik baru.
\end{abstract}

Kata Kunci: Antibiotik; Bakteri endofit; Taman Nasional Pulau Jawa 


\section{PENGANTAR}

Kebutuhan antibiotik jenis baru cenderung meningkat selama 20 tahun terakhir. Selama tahun 1979-2000 kebutuhan ini mencapai 200\% (Lockhart dkk, 2009). Antibiotik digunakan secara luas di bidang kemoterapi, penyakit tanaman, obat-obatan ternak, bioteknologi, dan biologi molekuler (Smitha \& Philip, 2014). Munculnya resistensi menjadi pemicu pencarian antibiotik baru, seperti PBL (penyakit busuk lunak) pada tangkai bunga anggrek (Joko dan Kusumandari, 2014), serta blas daun dan leher pada padi gogo lahan kering (Nasution dkk, 2014). Patogen pada manusia di oesophagus, vulvovaginal, dan kulit oleh Candida albicans banyak diteliti untuk penemuan anti jamur (Muhammed dkk, 2012). Penyakit moler pada daun bawang merah (Lestiyani dkk, 2014) dan busuk pada buah nanas dan mangga oleh Fusarium sp (Widiastuti dkk, 2014). Sumber antibiotik 20 tahun terakhir adalah isolat mikrobia tanah, yaitu bakteri khamir dan jamur. Mikrobia endofit memiliki inang dengan jenis, karakter, dan ekosistem yang bervariasi, sehingga berpeluang ditemukan jenis yang beragam. Pada kondisi lingkungan yang relatif berubah di antara jaringan tanaman, mikrobia endofit menghasilkan antibiotik dengan bioaktivitas yang lebih tinggi dibanding mikrobia yang diisolasi dari tanah atau permukaan tanaman (Strobel dkk, 2004; He, 2009).

Bakteri endofit hidup di antara jaringan tanaman dengan tanpa menunjukkan gejala kerusakan inang. Senyawa bioaktif diproduksi oleh bakteri endofit, di antaranya berfungsi sebagai pengendali patogen (Patel dkk, 2012). Bakteri endofit hidup bersimbiosis mutualisme dengan tanaman, hidup dalam berbagai kondisi di dalam tanaman, tanaman hidup pada berbagai kondisi lingkungan yang sangat bervariasi, dan tanaman memiliki banyak spesies. Kondisi tersebut memberi peluang yang besar untuk ditemukan spesies bakteri baru atau senyawa antibiotik baru.

Senyawa bioaktif dengan bioaktivitas tinggi dapat ditemukan pada tumbuhan hutan hujan tropis, telah lama terbukti digunakan dalam pengobatan masyarakat, dan tumbuh endemik pada suatu wilayah dan hidup pada kondisi khusus (unik) dan tidak biasa (Strobel $\mathrm{dkk}, 2004)$. Penelitian membuktikan isolat asal beberapa taman nasional di Pulau Sumatera, Jawa, dan Bali mempunyai efektivitas tinggi terhadap beberapa bakteri patogen tanaman (Meliawati dkk, 2006). Margino (2008) juga melaporkan bahwa isolat yang berasal dari tanaman langka di Yogyakarta mengindikasikan dapat diaplikasikan sebagai anti jamur. Isolat asal Taman Nasional di Pahang Malaysia berkhasiat sitotoksik dan antibakteri (Hazalin dkk, 2009) dan sebagai surfaktan penghambat pertumbuhan jamur Fusarium sp (Snook dkk, 2009).

Pada penelitian ini dilakukan isolasi dan seleksi bakteri endofit asal tanaman Taman Nasional di Pulau Jawa sebagai agen penghasil antibiotik dengan mikrobia uji dari jasad prokaryotik (Bacillus subtilis) dan eukaryotik (Candida albicans dan Fusarium oxysporum). B. subtilis adalah bakteri gram positif penyebab patogen, Candida albicans penyebab patogen manusia, dan Fusarium oxysporum adalah jamur patogen penyerang tanaman budidaya.

\section{Metode Penelitian Sumber Isolat}

Sampel yang digunakan berupa potongan ranting pohon yang diambil dari lokasi Taman Nasional Ujung Kulon, Meru Betiri Jember, Baluran Situbondo, Kebun Raya Bogor, dan hutan di Pulau Nusakambangan, masing-masing dimasukkan ke dalam plastik baru, dikumpulkan, dan disimpan dalam kotak pendingin (ice box) suhu $4^{\circ} \mathrm{C}$.

\section{Isolasi Bakteri Endofit}

Ranting pohon dipotong sepanjang 1 $\mathrm{cm}$, sterilisasi permukaan dilakukan dengan merendam di dalam larutan Bayclean atau Chlorox 5\% selama 5 menit, diikuti dengan perendaman air steril selama 2 menit, dipindahkan ke dalam larutan alkohol 70\% selama 1 menit, setelah itu dikering anginkan untuk menghilangkan akses air, kemudian 
dibelah membujur menjadi dua bagian. Permukaan belahan ditempelkan di atas medium Nutrient Agar (Margino, 2008), dan diinkubasi selama 24-28 jam pada petridish. Koloni bakteri dipindahkan ke medium agar miring sebagai kultur stok murni.

\section{Seleksi Bakteri Endofit Penghasil Antimikrobia (Antibiotik)}

Isolat-isolat bakteri endofit ditumbuhkan pada $10 \mathrm{ml}$ medium nutrien cair, GY (glucose yeast extract) dan antibiotik-3, kemudian diinkubasi pada suhu kamar $30^{\circ} \mathrm{C}$ dengan gojogan kecepatan 175 ketukan permenit selama 24-48 jam (Margino, 2008). Sel dipisahkan dengan sentrifugasi pada kecepatan 8000 rpm selama 15 menit pada suhu $4^{\circ} \mathrm{C}$ dalam tabung eppendorf. Supernatan dipisahkan untuk selanjutnya digunakan pada seleksi bakteri.

Seleksi dilakukan dengan metode paperdisc diffusion technique dengan cara mencelupkan paperdisc berdiameter $10 \mathrm{~mm}$ ke dalam supernatan dan dikurangi kebasahannya dengan meletakkan kertas paperdisc pada kaca steril selama kurang lebih 5 menit. Paperdisc kemudian diletakkan pada permukaan medium dalam petridish yang telah diinokulasi jasad indikator, yaitu medium nutrien, agar untuk pengujian dengan jasad Bacillus subtilis diinkubasi pada suhu $30^{\circ} \mathrm{C}$ selama 24-48 jam, medium GY digunakan untuk pengujian dengan jasad Candida albicans diinkubasi pada suhu $30^{\circ} \mathrm{C}$ selama 24-72 jam,dan medium PDA (potato dextrose) supaya untuk pengujian dengan Fusarium oxysporium diinkubasi pada suhu $30^{\circ} \mathrm{C}$ selama 24-72 jam. Terbentuknya zona jernih di sekitar paperdisc menggambarkan adanya aktivitas penghambatan oleh senyawa antimikrobia (antibiotik) terhadap mikrobia indikator (Mubin, 1999 dan Nugroho, 2009).

\section{Identifikasi Pendahuluan Senyawa Antimikrobia (Antibiotik)}

Penetapan senyawa antimikrobia pada supernatan dilakukan teknik kromatografi kertas. Spooting supernatan pada kertas kromatografi (Advantec Company, Jepang) sebanyak $20 \mu \mathrm{L}$ dengan menggunakan micro syringe dikembangkan dengan lima eluen, yaitu eluen A (amonium klorida 20\% dalam akuades), B (akuadesyang dijenuhi butanol), C (butanol : asam asetat: akuades $=3: 1: 1$ ), $\mathrm{D}$ (aseton : butanol : akuades $=5: 4: 1$ ), dan E akuades yang dijenuhi asam asetat (Margino, 1998). Bercak kromatogram yang dihasilkan, kemudian diidentifikasi dengan teknik bioassay menggunakan mikrobia indikator Bacillus subtilis, Candida albicans, dan Fusarium oxysporium.

\section{HASIL DAN PEMBAHASAN Isolasi Bakteri Endofit}

Isolasi dilakukan dari 273 tanaman yang berasal dari Taman Nasional Ujung Kulon Banten, Kebun Plasma Nutfah Indonesia (Kebun Raya Bogor), Pulau Nusakambangan (Cilacap), Taman Nasional Kaliurang, Taman Nasional Meru Betiri (Jember), dan Taman Nasional Baluran Situbondo. Hasil isolasi bakteri endofit diperoleh 304 isolat dari seluruh lokasi (Tabel 1). Meliawati et al (2006) pada penelitiannya melaporkan isolasi bakteri endofit dari beberapa tanaman asal Taman Nasional dan hutan di Pulau Jawa, Sumatera, dan Bali diperoleh 238 isolat bakteri endofit dari 126 tanaman.

Tabel 1.

Data Jumlah Tanaman dan Isolat Bakteri Endofit

\begin{tabular}{lll}
\hline $\begin{array}{c}\text { Lokasi Pengambilan } \\
\text { Tanaman }\end{array}$ & \multicolumn{1}{c}{$\begin{array}{c}\text { Jumlah } \\
\text { Tanaman }\end{array}$} & $\begin{array}{c}\text { Jumlah } \\
\text { Isolat }\end{array}$ \\
\hline Taman Nasional Ujung & 53 & 54 \\
Kulon Banten & 14 & 17 \\
$\begin{array}{l}\text { Kebun Raya Bogor } \\
\text { Pulau Nusakambangan }\end{array}$ & 35 & 38 \\
$\begin{array}{l}\text { Taman Nasional } \\
\text { Kaliurang }\end{array}$ & 45 & 58 \\
$\begin{array}{l}\text { Taman Nasional Meru } \\
\text { Betiri }\end{array}$ & 104 & 115 \\
$\begin{array}{l}\text { Taman Nasional } \\
\text { Baluran }\end{array}$ & 22 & 22 \\
\hline Jumlah & 273 & 304 \\
\hline
\end{tabular}

\section{Seleksi Bakteri Endofit}

Seleksi bakteri endofit dilakukan berdasar kemampuan tumbuh pada berbagai 
medium dengan sumber karbon yang berbeda dan menghasilkan daya hambat terhadap mikrobia indikator Bacillus subtilis, Candida albicans dan Fusarium oxysporum. Produksi antibiotik dilakukan dengan menumbuhkan isolat pada medium fermentasi dengan komposisi tertentu dan mampu menghasilkan senyawa metabolit sekunder, seperti yang terkandung dalam tanaman inang (Harni et al., 2010). Media yang digunakan pada penelitian ini adalah

nutrien cair, GY (glucose and yeast-extract) dan antibiotik 3 .

Pada penelitian ini, 304 isolat diujikan pada tiga macam media dengan tiga mikrobia indikator. Isolat terpilih adalah yang memiliki daya hambat senyawa antibiotik terhadap mikrobia indikator. Daya hambat dihitung sebagai diameter batas lingkaran terluar dari zona jernih penghambat dikurangi dengan diameter paperdisc. Jumlah isolat yang mampu menghasilkan senyawa antibiotik adalah 163 isolat (Tabel 2).

Tabel 2.

Jumlah Isolat Penghasil Senyawa Antibiotik dalam Media Nutrien Cair, GY dan Antibiotik 3 dengan Indikator Bacillus Subtilis, Candida Albicans, dan Fusarium Oxysporum.

\begin{tabular}{lllll}
\hline \multirow{2}{*}{ Media } & \multicolumn{2}{l}{ Mikrobia Indikator } & \multirow{2}{*}{ Jumlah Isolat Tiap Medium } \\
\cline { 2 - 5 } & B.subtilis & C.albicans & F.oxysporium & \\
\hline Nutrien cair & 54 & 13 & 7 & 74 \\
GY & 25 & 26 & 7 & 58 \\
Antibiotik 3 & 7 & 13 & 11 & 31 \\
\hline Jumlah & & & & 163 \\
\hline
\end{tabular}

Presentase isolat bakteri endofit yang menghasilkan senyawa antibiotik menggunakan tiga macam medium dan tiga jenis mikroba indikator dapat dihitung dengan cara membagi jumlah isolat setiap medium dengan jumlah total seluruh isolat bakteri endofit yang didapat. Medium Nutrien cair yaitu $\frac{74}{304} \times 100 \%=24,32 \%$, medium GY yaitu $\frac{58}{304} \times 100 \%=19,07 \%$, dan medium antibiotik-3 yaitu $\frac{31}{304} \times 100 \%=10,2 \%$. Menurut perhitungan tersebut, dapat dilihat bahwa penggunaan medium Nutrien cair diperoleh presentase isolat bakteri endofit dengan kemampuan antibiotik terbanyak, diikuti dengan medium GY, dan antibiotik-3. Hal ini diduga karena bakteri menghasilkan senyawa antibiotik dalam medium yang lebih sederhana seperti pada medium Nutrien cair (Margino, 2008). Medium Nutrien cair juga digunakan dalam memproduksi senyawa antibiotik dari Mycobacterium testaceum (Zinniel dkk, 2002), senyawa antipatogen tanaman (Meliawati dkk., 2006), dan senyawa biokontrol terhadap Fusarium verticullioides (Snook dkk, 2009).

Isolat bakteri endofit yang mampu menghasilkan senyawa antibiotik tersebut, selanjutnya dipilih yang memiliki daya hambat lebih dari 2,5 sebagai kandidat isolat unggul. Dari 163 isolat, ada 28 isolat yang memiliki daya hambat lebih dari 2,5 yang terdiri dari 12 isolat mampu menghambat Bacillus subtilis, 9 isolat mampu menghambat Candida albicans, dan 7 isolat menghambat Fusarium oxysporum (Tabel 3).

Tabel 3

Daya Hambat Isolat Bakteri Endofit yang Unggul pada Berbagai Media dengan Mikrobia Indikator

\begin{tabular}{l|l|l|l|l|l}
\hline \multirow{2}{*}{ No } & \multicolumn{2}{|c|}{ Medium } & \multirow{2}{*}{ Kode Isolat } & \multicolumn{3}{|c}{ Daya hambat isolatpada berbagai mikrobia indikator } \\
\cline { 4 - 6 } & & \multicolumn{2}{|c}{ B. subtilis } & C. albicans & F. oxysporum \\
\hline 1 & Nutrien cair & KLP-1 & 5 & & 3,6 \\
2 & Nutrien cair & TGP-1 & 4,6 & &
\end{tabular}




\begin{tabular}{|c|c|c|c|c|c|}
\hline \multirow{2}{*}{ No } & \multirow{2}{*}{ Medium } & \multirow{2}{*}{ Kode Isolat } & \multicolumn{3}{|c|}{ Daya hambat isolatpada berbagai mikrobia indikatol } \\
\hline & & & B. subtilis & C. albicans & F. oxysporum \\
\hline 3 & Nutrien cair & AMP-1 & 4,6 & & \\
\hline 4 & Nutrien cair & KBY-1 & 3,8 & & \\
\hline 5 & Nutrien cair & NGK-1 & 3 & & \\
\hline 6 & Nutrien cair & BIN-1 & 5,8 & 3 & \\
\hline 7 & Nutrien cair & SMN-1 & 2,8 & & \\
\hline 8 & Nutrien cair & TRG-1 & 2,6 & 3 & \\
\hline 9 & Nutrien cair & AGT-1 & 3 & & \\
\hline 10 & Nutrien cair & SWN-1 & 4 & & \\
\hline 11 & Nutrien cair & MDN-1 & 5 & & \\
\hline 12 & Nutrien cair & SLM-1 & 6 & & \\
\hline 13 & GY & KLY-1 & 3 & 3,6 & 2,8 \\
\hline 14 & GY & WGU-1 & 2 & & 4 \\
\hline 15 & GY & CMB-1 & & 4 & 3 \\
\hline 16 & GY & WRC-1 & 3 & 3 & \\
\hline 17 & GY & KLR-1 & 5 & & \\
\hline 18 & GY & $\mathrm{OOH}-1$ & 4 & 4 & 6 \\
\hline 19 & GY & STG-1 & & 4 & 6 \\
\hline 20 & GY & CMB-2 & & 4,3 & \\
\hline 21 & GY & CUR-1 & & 4,6 & \\
\hline 22 & Antibiotik 3 & STL-1 & & 4 & 4 \\
\hline 23 & Antibiotik 3 & KLC-1 & 2,7 & & \\
\hline 24 & Antibiotik 3 & MTG-1 & 3 & 3,8 & 4 \\
\hline 25 & Antibiotik 3 & KLY-2 & 2,8 & 3 & 3 \\
\hline 26 & Antibiotik 3 & CMB-1 & & & 2,8 \\
\hline 27 & Antibiotik 3 & PPH-1 & 2,1 & 4 & 4 \\
\hline 28 & Antibiotik 3 & TDE-1 & & & 4 \\
\hline
\end{tabular}

Pembagian jenis sasaran terhadap mikrobia prokaryot dan eukaryot perlu dilakukan dikaitkan dengan aplikasi, selanjutnya yaitu untuk bidang pertanian dan kesehatan manusia. Pengelompokan sasaran mikrobia prokaryot diuji dengan mikrobia indikator Bacillus subtilis, sedangkan sasaran eukaryot diindikasi dengan Candida albicans dan Fusarium oxysporum. Tabel 3 menunjukkan adanya isolat dengan daya hambat tinggi, yaitu sama dan lebih dari empat dan mampu menghambat lebih dari satu mikrobia indikator. Seleksi menggunakan medium Nutrien cair diperoleh isolat BIN-1 dan KLP1; dengan medium $\mathrm{GY}$ diperoleh isolat $\mathrm{OOH}$ -
1, STG-1, dan CMB-2, sedangkan dengan medium Antibiotik-3 diperoleh isolat STL-1, MTG-1, dan PPH-1. Seleksi berikutnya adalah penentuan senyawa antimikrobia yang dihasilkan oleh delapan isolat bakteri endofit tersebut berdasar pada tingkat kepolaran komponen sampel terhadap beberapa eluen. Seleksi dilakukan dengan metode kromatografi kertas sebagai identifikasi pendahuluan senyawa antimikrobia.

\section{Identifikasi Pendahuluan Senyawa Antibiotik}

Identifikasi pendahuluan bertujuan untuk mengetahui substansi-substansi yang 
menyebabkan penghambatan pada pertumbuhan jasad indikator. Identifikasi dilakukan terhadap supernatan dari isolat dengan teknik kromatografi kertas yang dilakukan dengan berbagai eluen. Teknik kromatografi kertas berdasar pada tingkat polaritas senyawa antibiotik dan beberapa macam senyawa yang dikandung dalam larutan ekstraseluler bakteri endofit yang ditumbuhkan dalam berbagai medium.

Angka polaritas eluen atau pelarut adalah sifat fisik senyawa antibiotik terhadap pengaruh eluen. Angka tersebut me- nentukan jarak pergerakan "bercak" dari tempat totolan mencapai jarak tertentu, nilai ini selanjutnya sebagai retardation force (Rf) sesudah dibandingkan dengan jarak di mana titik elusi diakhiri. Teknik tersebut telah digunakan dalam penelitian identifikasi pendahuluan senyawa antibiotik yang dihasilkan oleh fungi endofit dengan eluen yang terdiri dari amonium klorida, butanol, aseton, asam asetat, dan air dengan berbagai perbandingan (Margino, 2008). Nilai Rf dari delapan isolat bakteri endofit ditampilkan pada Tabel 4 .

Tabel 4.

Nilai Rf Isolat Bakteri Endofit yang Unggul dengan Eluen ABCDE

\begin{tabular}{l|l|l|l|l|l|l|l}
\hline \multirow{2}{*}{ No } & \multirow{2}{*}{ Kode Isolat } & \multicolumn{1}{|c|}{ Mikrobia Indikator } & \multicolumn{5}{|c}{ Nilai RF antibiotik dalam eluen } \\
\cline { 4 - 7 } & & A & B & C & D & E \\
\hline 1 & KLP-1 & B.subtilis & 0,90 & & & & \\
2 & BIN-1 & B.subtilis & 0,70 & 0,95 & 0,90 & & \\
3 & CMB-2 & C.albicans & & & 0,80 & & \\
4 & OOH-1 & C.albicans & 0,82 & 0,90 & & & \\
5 & STG-1 & C.albicans & & & & & \\
6 & STL-1 & F.oxysporium & & & & 0,99 & 0,90 \\
7 & MTG-1 & F.oxysporium & & & & & \\
8 & PPH-1 & F.oxysporium & & & & & \\
\hline
\end{tabular}

Antibiotik yang dihasilkan oleh STG-1 memiliki nilai Rf 0,82 setelah dielusi dengan amonium klorida dan nilai $\mathrm{Rf} 0,90$ pada eluen air yang dijenuhi butanol. Hal ini dapat dikatakan bahwa eluen tersebut dapat digunakan untuk proses ekstrasi dalam produksi antibiotik tersebut. Demikian halnya untuk antimikrobia yang dihasilkan isolat CMB-2 memiliki Rf 0,80 setelah dielusi dengan satu jenis eluen, yaitu air yang dijenuhi butanol, sehingga diduga antibiotik CMB-2 memiliki dua senyawa yang berbeda. Isolat $\mathrm{OOH}-1$ memiliki Rf 0,90 setelah dielusi dengan satu jenis eluen, yaitu akuades yang dijenuhi asam asetat. Margino (2008) melaporkan bahwa jika senyawa antimikrobia dapat dielusi dengan satu eluen yang sama, maka dapat dimungkinkan memiliki jenis antibiotik yang sama. Antibiotik yang berbeda dapat dianalisis jika menggunakan eluen yang berbeda.

\section{SIMPULAN}

Isolasi bakteri endofit diperoleh 304 isolat dari 273 tanaman. Seleksi menghasilkan 8 isolat unggul dengan daya hambat lebih dari 4 yaitu BIN-1, KLP-1, OOH-1 ,STG1, CMB-2, STL-1, MTG-1, dan PPH-1. Identifikasi pendahuluan senyawa antibiotik dilakukan dengan kromatografi kertas pada berbagai eluen dan didapatkan 3 isolat yang unggul, yaitu OOH-1, STG-1, dan CMB2. Hal ini menunjukkan bahwa mikrobia endofitik dalam pohon merupakan sumber yang potensial untuk mendapatkan bakteri penghasil antibiotik baru. 


\section{DAFTAR PUSTAKA}

Joko, T. dan Kusumandari, N. 2014. “Deteksi molekuler bakteri penyebab penyakit busuk lunak pada anggrek menggunakan teknik Polymerase Chain Reaction. Pengembangan dan pemanfaatan IPTEKS untuk kedaulatan pangan." Seminar Nasional Dies Natalis Faperta UGM ke-68. Yogyakarta: UGM.

Harni, R., Supramana., Sinaga M.S., Giyanti dan Supriyadi. 2010. "Pengaruh Filtrat Bakteri Endofit Terhadap Normalitas Penetasan Telur dan Populasi Nematoda Peluka Akar Pratylen chus brachyurus pada Nilam." Journal Litr, 16(1):43-47.

He. R.I., Wang. G.P., Liu. X.H., Zhang, C.L and Lin.F.C. 2009. "Antagonistic bioactivity of an endophytic bacterium isolated from Epimedium brevicornu." Maxim African Journal of Biotecnology, 8. (2): 191-195.

Lestiyani A.; Wibowo A.; Subandiyah S. 2014. “Uji Metode Inokulasi Pada Bawang merah dengan Fusarium spp. Pengembangan dan Pemanfaatan IPTEKS untuk Kedaulatan Pangan." Seminar Nasional Dies Natalis Faperta UGM ke-68. Yogyakarta: UGM.

Lockhart, SL., Kiederma DJ., dan Pfaller MA. 2009. "The Epidemiology of Fungal Infection." Diedit oleh Anaissie, EJ, Mc Ginnis MR, Pfaller MA. Journal of Clinical Mycologv. Edisi kedua. Oxford V K Elsevi Sp Inc.

Margino S., 2008. "Produksi metabolit sekunder (antibiotik) oleh jamur endofit." Majalah Farmasi Indonesia, 19:86-94.

Meliawati R, Widyaningrum D.N., Djohan A.C., dan Sukiman, H. 2006. "Pengkajian Bakteri Endofit Penghasil Senyawa Bioaktif untuk Proteksi Tanaman." Jurnal Biodiversitas, 7(3):221-224.

Mubin, F. 1999. "Kajian Produksi Senyawa Antimikrobia oleh Mikrobia Endofit."
Skripsi. Fakultas Pertanian Universitas Gadjah Mada.

Muhammed,M., Fuchs, B., Wu, M.P., Breger. J., Coleman J.J., dan Mylonakis. E. 2012. "The role of mycelium production and a MAPK-mediated imune response in the C. elegans Fusarium model system." Journal of Medical Mycology, 50(5) 488-496.

Nasution A., Usyati, N., dan Santosa. 2014. "Varietas lokal padi sebagai sumberketahanan penyakit blas daun dan blas leher. Pengembangan dan pemanfaatan IPTEKS untuk kedaulatan pangan." Seminar Nasional Dies Natalis Faperta UGM ke68. Yogyakarta: UGM.

Nugroho E., 2009. “Potensi Daya Antibakteri isolat Lactobacillus dari Tempoyak Escherichia coli." Seminar Hasil Penelitian dan Pengabdian Masyarakat. Uniba.

Patel., H.A. Khristi., SM, Perikh. K, Rajeram G. 2012. "Isolation and Characterization of Bacterial endophytic from Lycopersicum esculentum plant and their plant promoting characteristics." Nepal. Journal of Biotechnology, 2 (1):37-52.

Smitha SL and Philip RK. 2014. "Antibiotik Organic Compoundproduction by a marine fungus Pencillium cirinum S36 through solid state fermentation: optimization by response surface methodology." International Journal of Research Biomedicine and Biotechnology, 4(1):6-13.

Snook, M. E., Mitchel, T., Hinton, D. M., dan Bacon, C. W., 2009. Isolation and Characterization of Leu surfaction from the endophytic bacterium B.mojavensis RRC. 101., a Biocontrol for Fusarium verticulodies. Journal of Agriculture and Food Chemical, 57:4287-4292.

Strobel G., Daisy B., Castillo U., Harper J. 2004. "Natural Product from 
JURNAL 『ERKNOSAINS | VOL 5, NO. 1, DESEMBER 2015; 1-8

Microorganism." Journal of Natural Product, 67:257-269.

Widiastuti, A. dan Ningtyas, O. H. 2014. "Identifikasi jenis jamur penyebab busuk pada beberapa buah pasca panen di Yogyakarta. Pengembangan dan pemanfaatan IPTEKS untuk kedaulatan pangan." Seminar Nasional Dies Natalis Fapefta UGM ke68. Yogyakarta: UGM.
Zinniel, D. K., Lambrecht; Harris, N. B.; Fang, Z; Kuczmarsk, I. D.; Higley, P; Ishimaru, C; Arunakumari, A; Barletta, R. G.; Vidaver, A. K. 2002. "Isolation and Characterization of Endophytic Colonizi Bacteria from Agronomic Crops and Praire Plant." Applied Environment Microbiology. 68(5):2198-2108. 